\title{
EXPLORING MOTIVATION AND CLIL: A LITERATURE REVIEW
}

\author{
Marta del Pozo Beamud, Universidad de Castilla-La Mancha \\ E-mail: marta.pozobeamud@uclm.es
}

\begin{abstract}
This article intends to explore the history of motivation whithin the field of second or foreign language learning. To this end, we will analyse in detail the three most important models: the Socio-Educational Model, the Theory of Self-Determination and the L2 Motivational Self System. We will also analyse the relationship between motivation and CLIL, concluding that this approach is very motivating for such students, since they are more motivated than their counterparts who study English in a more traditional way.
\end{abstract}

Key words: L2 motivation, L2 selves, Socio-Educational Model (SEM), bilingualism, CLIL, gender.

Resumen: A través de este artículo se pretende realizar un recorrido por la historia de la motivación en el ámbito del aprendizaje de una segunda lengua o de una lengua extranjera. Para ello, analizaremos en detalle los tres modelos más importantes: el Modelo Socioeducativo, la Teoría de la Autoderminación y el Sistema del Yo Motivacional en L2. Asimismo, analizaremos también la relación entre la motivación y AICLE, concluyendo que dicho enfoque resulta muy motivador para sus alumnos, quienes están más motivados que sus compañeros que estudian inglés de forma tradicional.

Palabras clave: Motivación en L2, los yoes en L2, el Modelo Socio-Educativo (MSE), bilingüismo, CLIL, género.

\section{INTRODUCTION}

Many authors have ventured to study the complex realm of learning a second/foreign language. Acquiring the mother tongue and learning a foreign language are quite the opposite (Moya Guijarro, Albentosa Hernández \& Jiménez Puado, 2003: 11). Unlike the mother tongue, which is acquired without conscious effort, a second or a foreign language is normally learned in formal contexts (Marsh, 2000: 2, 3). Thus, the acquisition/learning processes are totally different and learning languages can be complicated for some people, though others seem to have a natural talent for it (Marsh, 2000: 2, 3, 4). Nonetheless, when analysing how individuals learn we cannot solely take into consideration factors such as intelligence and/or language skills due to the fact that the human being is a complex organism. It is most important, for example, to pay attention to affective variables such as motivation or anxiety. Authors such as Krashen and his "Affective Filter Theory" (Krashen, 1982) made these factors gain momentum within the field of Applied Linguistics. 


\section{THE SOCIO-EDUCATIONAL MODEL (SEM)}

The Socio-Educational Model or SEM seems pivotal when it comes to motivation. Its most important contribution, without a doubt, is the distinction between integrative motivation and instrumental motivation. Integrative motivation is made up of a series of favorable attitudes towards other ethnic communities, other groups in general and towards the language learning context, so it is expected that its influence will continue over time (Gardner \& MacIntyre, 1991: 70). In contrast, instrumental motivation is associated with a specific goal, so it will end once attained (Gardner \& MacIntyre, 1991: 70, 71). However, despite this difference, Gardner and MacIntyre (1991: 68) demonstrated that both are important with regard to learning a second language.

The SEM began to develop in the 60s (Gardner, 1960) and it has suffered multiple updates. As we can see in Figure1, there are four main variables to take into account when learning a language: group specific attitudes, course related characteristics, motivational indices and generalised attitudes (Gardner, 2010: 80). Within the first variable we find attitudes toward French Canadians and toward European French (Gardner, 2010: 80, 81). The second variable comprises attitudes toward learning French and toward the French course, in addition to parental encouragement to learn French and French class anxiety (Gardner, 2010: 81). The third variable is formed by integrative orientation, motivational intensity and by the desire to learn French (Gardner, 2010: 81, 82). Finally, the fourth variable relates to the interest in foreign languages, ethnocentrism, authoritarianism, anomie, Machiavellianism and need of achievement (Gardner, 2010: 81, 82).

$\begin{array}{llll}\text { Social } & \text { Individual } & \text { Acquisition } & \text { Outcomes } \\ \text { Milieu } & \text { Differences } & \text { Contexts } & \end{array}$

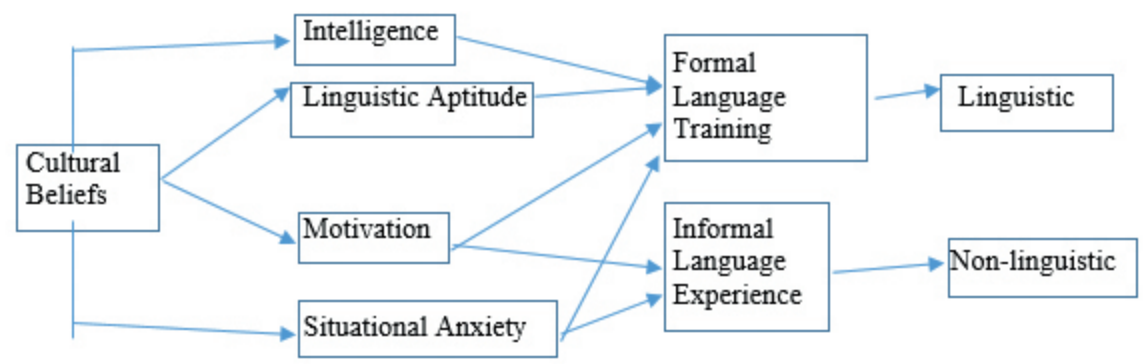

Figure 1. The original Socio-Educational Model (Gardner \& Smythe, 1974, 1975) extracted from Robert Gardner (2010: 81) 


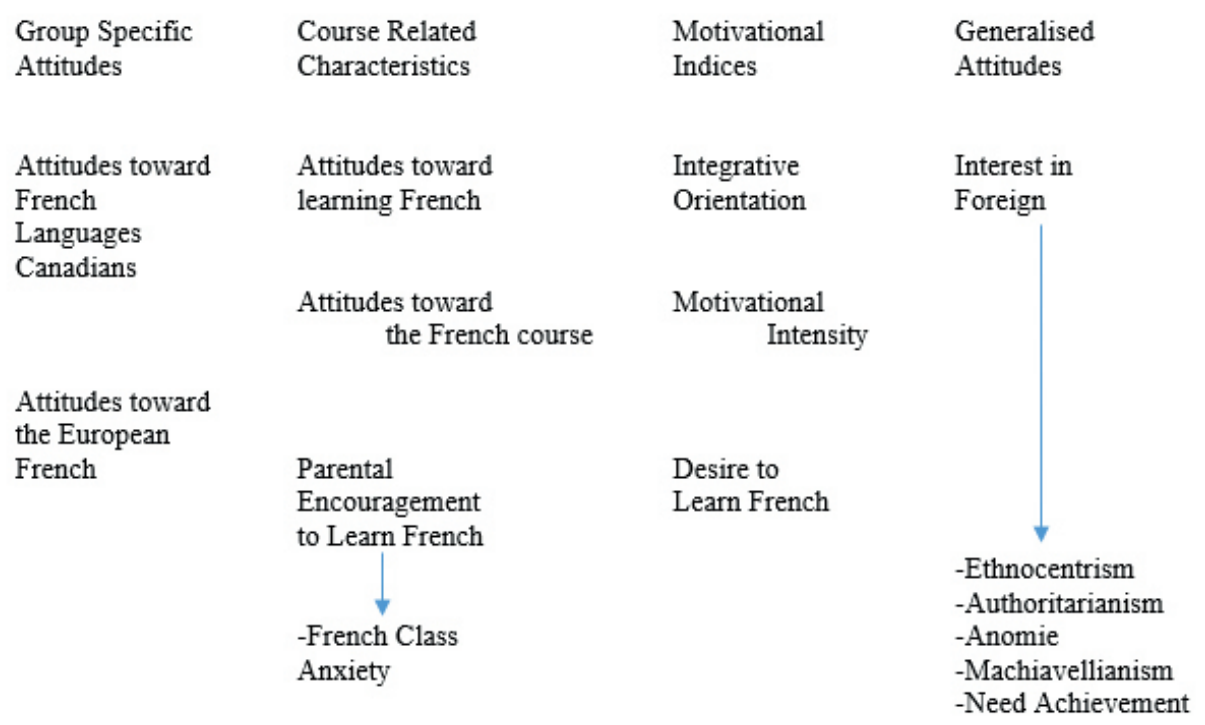

Figure 2. A slightly adapted version of the first formulation of the Socio-educational Model (Gardner, 1979) extracted from Robert Gardner (2010: 83)

In other versions (see figure 2), changes are observed. First of all, we find four main components: social milieu (cultural beliefs), individual differences (intelligence, linguistic aptitude, motivation and situational anxiety), acquisition contexts (formal language training and informal language experience) and learning outcomes (linguistic and non-linguistic) (Gardner, 2010: 83). Secondly, we can appreciate all the relationships that take place between these elements. Thus, cultural beliefs apparently influence intelligence, language aptitude, motivation and situational anxiety, all factors that, in turn, influence formal learning (institutional learning) (Gardner, 2010: 84). However, when talking about informal learning, motivation and anxiety have greater influence than the other factors (Gardner, 2010: 84). Finally, it is worth noting that both formal and informal learning translate into linguistic and non-linguistic results (Gardner, 2010: 85).

The following model (see figure 3 ) is similar to the previous one (figure 2), despite substantial differences between them. As we can appreciate, what was previously called the social milieu is now called the socio-cultural milieu. Besides, the acquisition contexts become learning acquisition contexts. What is more, individual differences are now divided into cognitive factors (intelligence, language aptitude and language learning strategies) and affective factors (attitudes and motivation, language anxiety and self-confidence), which influence both formal and informal contexts, by generating both linguistic and non-linguistic outcomes (Gardner \& MacIntyre, 1992).

Finally, Figure 4 represents a radical change with respect to all the previous ones (Figure 1), (Figure 2) and (Figure 3). As we can see in the following figure (Figure 4), this model has the following constructs: integrativeness, attitudes toward the learning situation, 
motivation, instrumentality, aptitude, language achievement, language anxiety and integrative motivation (Gardner, 2010: 88 -93).

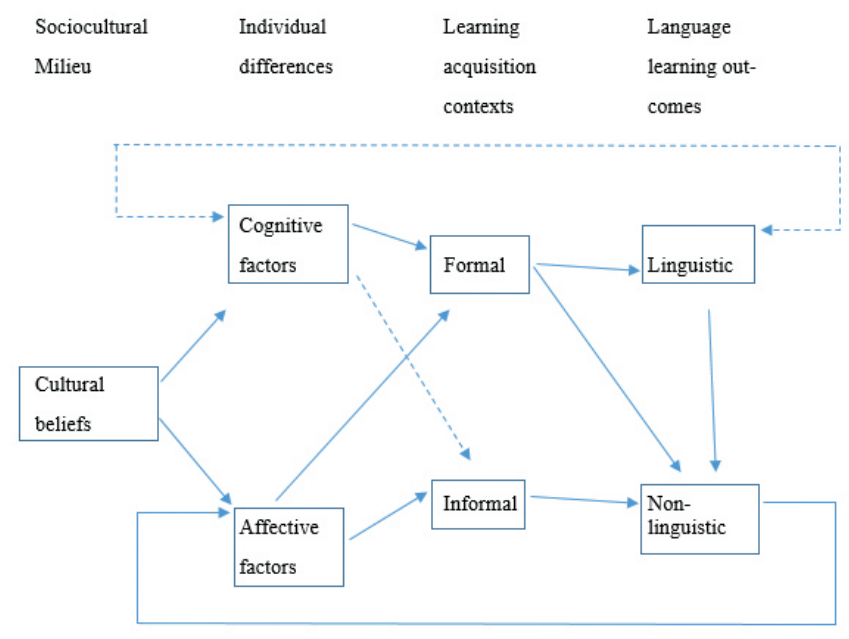

Figure 3. The Socio-Educational Model (Gardner \& MacIntyre, 1992) extracted from MacIntyre (2002: 47)

In the first place, let us address the integration construct. Integration was defined by Gardner (1982: 114) as "the attitudinal reactions towards other communities /ethnolinguistic groups, which may influence the degree to which individuals wish to accept certain behavior patterns of the other ethnolinguistic community" (Gardner, 1982: 114). This construct is composed of integrative orientation (IO), interest in foreign languages (IFL) and attitudes toward French Canadians (AFC) (Gardner, 2010: 89). Secondly, attitudes toward the learning situation construct is integrated by all the aspects that are part of the learning situation, that is, the teacher (TEACHER) and course (CLASS), with its materials, extracurricular activities, etc.) (Gardner, 2010: 89). Third, the motivational construct is composed of motivational intensity (MI), the desire to learn French (DESIRE) and attitudes toward learning French (ALF) (Gardner, 2010: 90), and is crucial when talking about language achievement (Gardner, 2010: 91). Fourth, instrumentality is composed of the instrumental orientation (INS) and exerts some influence on motivation (Gardner, 2010: 90). Fifth, linguistic anxiety is formed by language class anxiety (CLASS) and language use anxiety (USE). According to this model, this type of anxiety affects and is affected by language achievement (Gardner, 2010: 91). Finally, it is important to highlight the importance of the construct of integrative motivation, which does not appear in the graphic representation of this model. This type of motivation, as previously stated, was characterised by "the desire or will of the apprentices to identify with another linguistic community and to tend to assess the learning situation in a positive way" (Gardner, 2010: 91). 


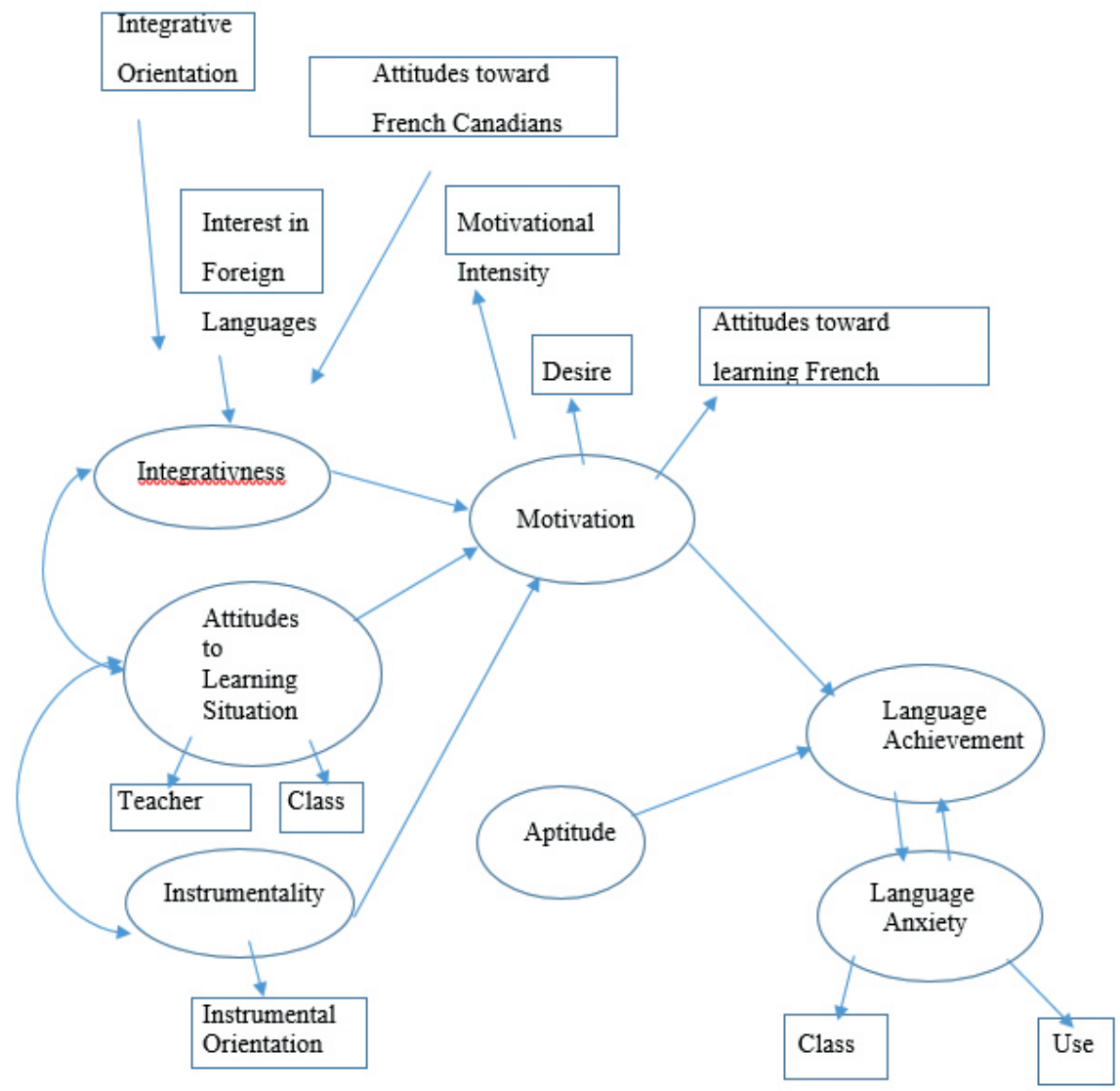

Figure 4. A structural equation representation of the SEM (Gardner, 2006) extracted from Robert Gardner (2010:88)

\section{THE SELF-DETERMINATION THEORY}

The Self-Determination Theory seems very relevant as well. It started within the field of psychology and due to its great applicability within the language learning field it soon began to be of great use for researchers of the field. It presents a continuum made up of extrinsic motivation, extrinsic motivation and amotivation (Ryan \& Deci: 2002, 16). Intrinsic motivation refers to the realisation of an activity out of pleasure and/or interest, whereas extrinsic motivation is related to the attainment of a specific goal (Deci \& Ryan, 2000). For its part, motivation is "the absence of any kind of motivation" (Dörnyei \& Ushioda 2011: 23), and it is usually associated with non-acting or passive behaviors (Ryan \& Deci 2002: 17). As we can see in Figure 5, extrinsic motivation is made up of four subtypes: 


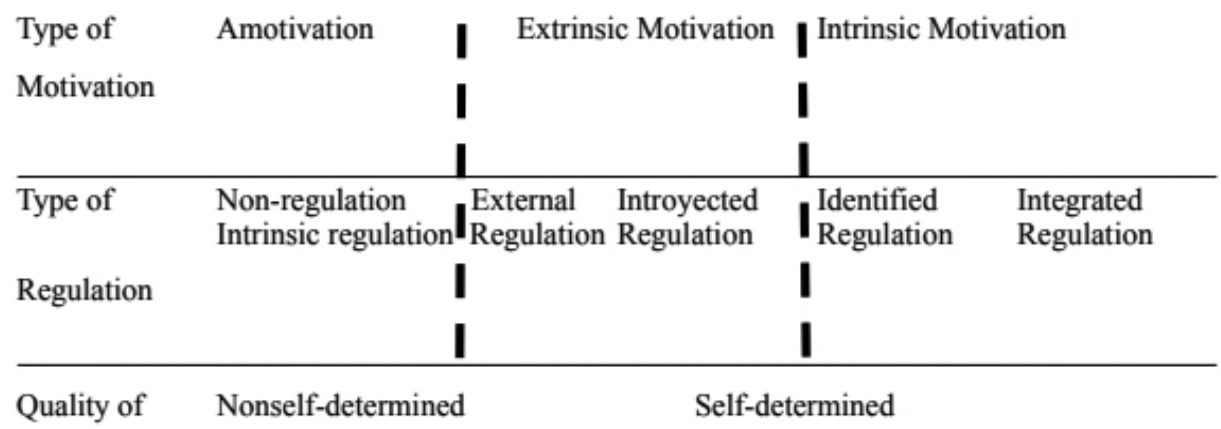

Behaviour

Figure 5. The Self-Determination Continuum, with Types of Motivation and Types of Regulation (Ryan \& Deci, 2002: 16)

External regulation involves rewards and punishments (Ryan \& Deci, 2002: 17). Thus, one could affirm that the individual is governed by external demands or contingencies from society (Ryan \& Deci, 2002: 17). Unlike external regulation, which is the least internalised regulation, introjected regulation is partially internalised, but not completely (Ryan \& Deci, 2002: 17). The most common feelings associated with this type of regulation are guilt and shame, amongst others (Ryan \& Deci, 2002: 17). Identified regulation or regulation through identification involves the passage of an external regulation to true self-regulation (Ryan \& Deci, 2002: 17). Nonetheless, it is sometimes the case that these regulations do not entirely reflect the thoughts and values of a person (Ryan \& Deci, 2002: 17, 18). Integrated regulation is considered the most internalised form (Ryan \& Deci, 2002: 18). In this case, a person's actions are ruled by his/her own values, goals and needs (Ryan \& Deci, 2002: 18). It is worth mentioning that integrated regulation is very similar to intrinsic motivation. Nonetheless, the former, although the most autonomous, is still associated with the attainment of a specific goal, whereas the latter has to do with the enjoyment of an activity per se (Ryan \& Deci, 2002: 18).

That being said, this continuum seems very useful when it comes to analysing L2/FL motivation in learners due to the fact that we can draw many conclusions depending on where an individual is on the continuum. What is more, correlations amongst the different types of motivation and achievement, goal attainment and so on, can be also established.

\section{THE L2 MOTIVATIONAL SELF SYSTEM}

This system is undoubtedly the most revolutionary in this process due to the fact that it combines both motivation and identity. In order to understand it better, it is necessary to know that part of the learning of a second language differs from the learning of other subjects, since a second language can become an intrinsic part of the individual. In the words of Dörnyei (2009: 9): “... L2 motivation researchers have always believed that a foreign language is more than a mere communication code that can be learned similarly to 
other academic subjects, and have therefore typically adopted paradigms that link the L2 to the individual's personal "core."”

Its foundations lie in the field of psychology and, amongst others, in the notion of possible selves (Dörnyei, 2009: 10). According to Markus and Nurius (1986: 954): "The possible selves are individual and personal, but at the same time social". In other words, each individual has their own desires, but by living within a society, many of these desires can be collective. Thus, these selves serve as bridges between the present and the future, between the current self and the future self (Markus \& Nurius 1986: 961), acting as future self-guides (Dörnyei, 2009: 11).

In addition to the possible selves, this system borrows two types of selves (the ideal and ought self), described by Higgins (1987: 320) in his Self-discrepancy Theory. For him, there are three types of selves: the actual self, the ideal self and the ought self. The actual self corresponds to reality and refers to the qualities that are possessed, the ideal self, on the other hand, is related to the qualities that one would wish to have, unlike the oughtto-be self, which is linked to the qualities that one feels one should have. In the words of Higgins (1976: 320, 321):

There are three basic domains of the self: (a) the current self, which is your representation of the attributes that someone (yourself or another) believes you actually possess; (b) the ideal self, which is your representation of the attributes that someone (yourself or another) would like, ideally, to possess (i.e., a representation of someone's hopes, aspirations, or wishes for, you); and (c) the ought self, which is your representation of the attributes that someone (yourself or another) believes you should or want to possess (i.e., a representation of someone's sense of your duty, or responsibilities).

Thus, taking into account these antecedents, we observe that, according to the L2 Motivational Self System, the motivation construct is integrated by the ideal L2 self, the ought-to L2 self and the L2 learning experience (Dörnyei, 2005: 105, 106). The ideal self, in this case, is related to the attributes that someone would like to possess in relation to the learning of a second language, for example, if the learner would like to improve some specific aspects (Dörnyei, 2005: 105). In addition, this self acts as a motivating factor reducing the distance between the actual self and the ideal self (Dörnyei, 2005: 105). The ought-to self does not refer to the qualities that someone would like to have, but to the qualities that someone should have (Dörnyei, 2005: 105). Thus, in order to avoid possible negative results, the individual is governed by obligations and responsibilities (Dörnyei, 2005: 105, 106). In the case of learning a second language or a foreign language, it is about the qualities that a student of an L2 / LE feels obliged to have. It is no longer about one's own desires, but about desires imposed from external sources. Finally, the learning experience is integrated not only by the learner's own experience, but also by the elements of the learner's learning context (Dörnyei, 2005: 106). This learning experience is an aspect that all researchers should take into account, since the context in which the learning takes place can both facilitate or completely destroy the motivation of the student.

Assimilating these multiple factors and being aware of their presence in the field of learning a second language or a foreign language is complex. In this way, so that the individual becomes more aware of the presence of the ideal self, Hadfiled and Dörnyei 
(2013: 5) emphasise the importance of the creation of a vision. Thus, the individual has to create a vision, striving to imagine himself as a second language speaker.

The next logical step in this continuum is to sustain the vision. This step is also crucial, since it assumes a filter through which the visions must pass in order to know if they are truly plausible and can be achieved realistically (Hadfield \& Dörnyei, 2013: 32). At this point, many of the visions do not transfuse this filter, since they are too unreal (Hadfield \& Dörnyei, 2013: 32). If we take as an example the case of the L2/FL student, he can visualise himself speaking or writing in the L2 / FL as a native speaker. However, this view is unrealistic. The moment the learner realises that this is not feasible, the vision runs the risk of vanishing.

Thirdly, compensating for the vision is of vital importance. In this way, the learner must count on the possibility of failure from the outset and must have strategies to deal with it and overcome it once this has occurred (Hadfield \& Dörnyei, 2013: 49). In other words, the individual has to be prepared for possible difficulties that may arise in this process and have the necessary tools to be able to emerge victorious from this situation of failure. Moreover, it is advisable to identify possible obstacles that may arise with the aim of moving forward (Hadfield \& Dörnyei, 2013: 49).

Fourth, the possible clashes between the ideal self and the ought-to self must be taken into account, so that, in order to avoid a conflict, the vision of both selves must be unified (Hadfield \& Dörnyei, 2013: 71). If we think again of a student of a second or foreign language, the ideal self would be related to aspects of such language that the student is willing to learn for his/her own interest or curiosity. On the other hand, the ought-to self would be related to passing exams in order to pass the subject/the course, get a better job, etc. Therefore, the learner has to find the equilibrium, the midpoint between these two selves to avoid possible collisions between them.

Finally, once all obstacles have been overcome, the student reaches the last step, in which he/she must try to enhance the vision. For this, the vision has to be more detailed, more tangible, more lasting and more concrete than the initial vision (Hadfield \& Dörnyei, 2013: 94). For instance, if the learner wishes to improve his/her level of oral or written English, practicing is the only way to achieve it.

So that this vision is not lost, it is advisable for the individual to set long-term goals, to later transform them into short-term goals and thus be able to achieve them more easily (Hadfield \& Dörnyei, 2013: 106). For a student, it is easier to see the subject of English as a continuum of activities rather than a whole subject. It does not matter if it is a primary, secondary or university student, since it is always better to overcome small obstacles than to face one of greater difficulty. In addition, these goals must be translated into plans (Hadfield \& Dörnyei, 2013: 127) and these into strategies (Hadfield \& Dörnyei, 2013: 146) until they end in achievement (Hadfield \& Dörnyei, 2013: 180).

\section{MOTIVATION AND CONTENT AND LANGUAGE INTEGRATED LEARNING (CLIL)}

Over the past years, the number of bilingual centers have been growing exponentially, due to the fact that bilingual education $(\mathrm{BE})$ is booming both nationally and internationally 
(Guadamillas Gómez, 2015: 112). It usually takes place within formal contexts (schools, institutes, universities, etc.) and its main am is that the students can learn two or more languages. In the words of Abello-Contesse (2013: 4): "BE is an umbrella term that refers to the regular use of two or more languages for teaching and learning in instructional settings when bilingualism and biliteracy are two of the explicit long-term goals." Bilingual education translates into different types of educational programs of a certain duration, in which the individual receives a certain content, through two or more vehicular languages in a systematized way. As Albello-Contesse (2013: 4) stated: "BE is generic concept that refers to various types of educational programs that provide systematic instruction in two (or more) languages for a prolonged period of time."

Within these programs, the most popular one all across Europe and Spain is CLIL (Content and Language Integrated Learning). What this programme offers to students is the possibility of learning both content and language simultaneously by studying non-linguistic content in a second/foreign language. In the words of Mehisto et al:

"CLIL is a dual-focused educational approach in which an additional language is used for the learning and teaching of both content and language" (Mehisto, Marsh \& Frigols, 2008: 9).

"CLIL is an approach or method which integrates the teaching of content from the curriculum with the teaching of a non-native language" (Bentley, 2010: 5).

"CLIL is an educational approach in which various language-supportive methods are used which lead to a dual-focused form of instruction where attention is given to both the language and the content" (Coyle, Hood \& Marsh 2010: 3).

The relationship between CLIL and motivation is not a straightforward one. Many researchers have found contradictory results in both in primary and secondary. In Rioja (Spain) Fernández Fontecha and Canga Alonso (2014: 25, 33) discovered amongst their primary school participants ( $4^{\text {th }}$ graders $)$ that EFL students were more motivated than CLIL students. Heras and Lasagabsater $(2015: 76,82)$, on their part, found no differences amongst CLIL and non-CLIL secondary education students in Navarra (Spain). Notwithstanding, the vast majority of studies carried out both in Spain and in Europe have obtained positive results. It has been demonstrated that students who are enrolled in CLIL programmes have more positive attitudes towards the learning of a language and also greater motivation in comparison to non-CLIL students (Doiz, et al., 2014; Lasagabaster, 2011; Lasagabaster \& López Beloqui, 2015; Lasagabster \& Sierra, 2009; Seikkula-Leino 2007). Thus, participants aged between 10 and 16 years old who take part in CLIL programmes in Spain and in Europe are usually more motivated than their non-CLIL counterparts (Doiz et al., 2014; Lasagabaster, 2011; Lasagabaster \& López Beloqui, 2015; Lasagabster \& Sierra, 2009; Seikkula-Leino, 2007).

\section{MOTIVATION, GENDER, L2 SELVES AND CLIL}

As we have seen (see figures 1-5 and tables 1, 2 and 3 in the Appendix for more information), the relationship between CLIL and motivation is worth taking into 
consideration. What is more, some authors have gone a step further by trying to analyse the role of gender within this relationship. Although the results can seem a bit inconsistent, studies have shown that in CLIL contexts both in Spain and in Europe that female students are normally more motivated than males.

Fernández-Fontecha (2014: 32, 39) showed in La Rioja (Spain) that CLIL girls in primary education (5th graders) were more motivated than CLIL boys. Girls were more intrinsically motivated than boys and boys, on the other hand, were more extrinsically motivated that their counterparts, although those differences were not statistically significant (Fernández-Fontecha, 2014: 39). However, Fenández-Fontecha and Canga Alonso (2014: 25,32 ), also in La Rioja, found very different results in that CLIL male students were more motivated that CLIL female students in primary education ( $4^{\text {th }}$ graders). Likewise, Heras and Lasagabaster $(2015: 76,84)$ reported identical results in Navarra (Spain), but this time amongst secondary education participants. Thus, CLIL male students were more motivated that their female counterparts.

Authors such as Lasagabaster and Sierra $(2009: 8,11)$ in the Basque Country (Spain), found that female CLIL students in secondary education $(M=15,5)$ within secondary education participants ( $M=15.5$ years old) that CLIL females had more positive attitudes towards English learning than males. Nonetheless, some years later authors like Doiz et al. (2014: 214, 218, 220) did not find any gender differences amongst students in secondary education ( $1^{\text {st }}$ and $3^{\text {rd }}$ grade $)$ in the Basque Country in relation to motivation.

In a similar vein, in Sweden, Sylvén and Thompson $(2015: 34,37)$ found, also in Secondary Education, that CLIL female students were more motivated than males as they showed more cultural interest, more interest in FLs, more international empathy and a stronger travel orientation, to name but a few. Based on these results, as Navarro Pablo and García Jiménez (2018: 87) stated, we can reaffirm that motivation happens to be more present in CLIL contexts than in non-CLIL contexts.

The relationship between L2 Selves and CLIL should be further explored since the literature on this subject is very scarce and somewhat contradictory. On the one hand, Mearns (2012: 176, 185, 186), was not able to demonstrate in England that CLIL was positive for the ideal self of her participants (high school students aged between 13 and 14 years old), perhaps because one of the activities carried out within the project could have had a negative effect on the ideal self of the respondents. This activity was evaluable and consisted of a group presentation in German, the respondents' foreign language, on a topic related to health (Mearns, 2012: 176, 181). However, Sylvén and Thomson (2015: 34, 35), in their study conducted in the Swedish context, found that secondary school participants who were part of the CLIL programme had a greater presence of the ideal self compared to those who were not part of such programme. What is more, Heras and Lasagabaster (2015: $77,84)$ also in secondary education analysed gender influence in CLIL contexts with regard to the selves and found that CLIL has an intensifying effect on males in relation to their ought-to self in addition to enhancing their ideal self. Finally, Sylvén (2017: 54) affirmed that bilingual programs such as CLIL are stimulating for the ideal self, since they encourage the use of language in a real way. Likewise, Sylvén (2017: 55) also affirmed that in nonbilingual centers traditional English classes can have a positive effect on the ideal self, and, 
on the other hand, a negative effect on the ought-to self of the students by the seemingly excessive attention that is paid to aspects such as grammar correction.

\section{CONCLUSIONS}

Research has shown the importance the different affective variables mentioned above when learning a second/foreign language. It would be counterproductive to ignore their importance in the classroom. By focusing only on aspects such as intelligence or reasoning we are setting aside a fundamental aspect of the human being, the affective part. As Martínez Lirola (2005: 33) points out, it is vitally important that the teacher make the classroom a comfortable environment where the student is the protagonist. Teachers should try to encourage and maintain the students' motivation through interesting, appropriate and challenging activities. Bilingual education or, more specifically, the CLIL approach has been proven to be a key approach when it comes to motivation, since participants enrolled in CLIL programmes are more motivated than their ELF counterparts. Therefore, more schools should join this new way of understanding, transmitting, learning and living a second or a foreign language.

\section{REFERENCES}

Abello-Contesse, C. 2013. "Bilingual and multilingual education: An overview of the field". Bilingual and multilingual education in the 21st century: Building on experience. Eds. C. Abello-Contesse, P. M. Chandler, M. D. López-Jiménez, \& R. Chacón-Beltrán, Bristol: Multilingual Matters. 3-23.

Bentley, K. 2010. The TKT course: CLIL module. Cambridge: Cambridge University Press.

Coyle, D., Hood, P., \& Marsh D. 2010. Content and language integrated learning. Cambridge: Cambridge University Press.

DeCI, E. L., \& RYAn, R. M. 2000. “The 'what' and 'why' of goal pursuits: Human needs and the self-determination of behavior". Psychological Inquiry, 11, 4: 227-268.

Doiz, A., Lasagabaster, D., \& Sierra, J. M. 2014. "CLIL and motivation: The effect of individual and contextual variables". The Language Learning Journal, 42(2), 209-224.

DöRNYEI, Z. 2005. The psychology of the language learner: Individual differences in second language acquisition. Mahwah, NJ: Lawrence Erlbaum.

DöRnYEI, Z. 2009. The L2 motivational self system. Motivation, language identity and the L2 self. Eds. Z. Dörnyei, Z., \& E. Ushioda. Bristol: Multilingual Matters. 9-42.

DöRNYEI Z., \& UsHIODA E. 2011. Teaching and researching motivation (2 $2^{\text {nd }}$ edition). Harlow: Pearson.

FERnÁNDEZ-FonTECHA, A. 2014. "Motivation and gender effect in receptive vocabulary learning: An exploratory analysis in CLIL primary education/Motivación y género en el aprendizaje del vocabulario receptivo: Un análisis exploratorio en educación primaria AICLE". Latin American Journal of Content \& Language Integrated Learning, 7, 2: 27-49. 
Fernánndez-Fontecha, A., \& CAnga Alonso, A. 2014. “A preliminary study on motivation and gender in CLIL and non-CLIL types of instruction". International Journal of English Studies, 14, 1: 21-36.

GARDNER, R. C. 1960. Motivational variables in second language acquisition. (Unpublished thesis). Montreal, Canada: McGill University.

GARDNER, R. C. 1979. Social psychological aspects of second language acquisition. Language and social psychology. Eds. H. Giles, \& R. St. Clair. Oxford: Basil Blackwell. 193-220.

GaRDNER, R. C. 1982. Language attitudes and language learning. Attitudes towards language variation. Eds. B. Ryan, \& H. Giles. London: Edward Arnold. 132-147.

GARDNER, R. C. 2010. Motivation and second language acquisition: The socio-educational model. New York: Peter Lang Publishing.

GARDNER, R. C. \& MacInTYRe, P. D. 1991. “An instrumental motivation in language study. Who says it isn't effective?" Studies in Second Language Acquisition, 13, 1: 57-72.

Gardner, R. C., \& MacIntyre, P. D. 1992. “A student's contribution to second language learning: Part I, Cognitive variables.” Language Teaching, 25, 4: 211-220.

Gardner, R. C., \& Smythe P. C. 1974. "The integrative motive in second-language acquisition". Bilingualism, Biculturalism and Education, 1: 31-45.

GARDNER, R. C., \& SMYTHE, P. C. 1975. "Second language acquisition: A social psychological approach". Research Bulletin No. 332.The University of Western Ontario.

HAdfield, J., \& DöRnYeI, Z. 2013 Motivating learning. Harlow: Pearson.

Guadamillas Gómez, M. V. 2016. "Elmer: A classroom intervention for intercultural bilingual education". Odisea $n^{\circ}$ 16: Revista de estudios ingleses, 16: 111-125.

Heras, A., \& Lasagabaster, D. 2015. "The impact of CLIL on affective factors and vocabulary learning". Language Teaching Research, 19, 1: 70-88.

Higgins, E. T. 1987. "Self-discrepancy: A theory relating self and affect". Psychological Review, 94(3), 319-340.

Krashen, S. D. 1982. Principles and practice in second language acquisition. Oxford: Pergamon Press.

LASAGABASTER, D. 2011. "English achievement and student motivation in CLIL and EFL settings". Innovation in Language Learning and Teaching, 5, 1: 3-18.

Lasagabaster D., \& Lopéz Beloqui, R. 2015. "The impact of type of approach (CLIL versus EFL) and methodology (book-based versus project work) on motivation". Porta Linguarum: revista internacional de didáctica de las lenguas extranjeras, 23: 41-57.

Lasagabaster, D., \& Sierra, J. M. 2009. "Language attitudes in CLIL and traditional EFL classes”. International CLIL Research Journal, 1, 2: 4-17.

MacInTYRe, P. D. 2002. Motivation, anxiety and emotion in second language acquisition. Individual differences and instructed language learning. Eds. P. Robinson. Amsterdam: John Benjamins. 45-68. 
Markus, H., \& Nurius, P. 1986. “Possible selves”. American Psychologist, 41, 9: 954-969.

MARsh, D. 2000. Using languages to learn and learning to use languages. Finlandia: University of Jyväskylä.

MartíneZ Lirola, M. 2005. “¿Qué relación guarda la motivación con los problemas de disciplina durante la adolescencia en los programas de educación bilingüe en EE.UU.?" Porta Linguarum: revista internacional de didáctica, 3: 21-34.

MeARns, T. L. 2012. “Using CLIL to enhance pupils' experience of learning and raise attainment in German and health education: A teacher research project". The Language Learning Journal, 40, 2: 175-192.

Mehisto P., March, D., \& Frigols M. J. 2008. Uncovering CLIL: Content and language integrated learning in bilingual and multilingual education. Oxford: Macmillan Education.

Moya Guijarro, A. J., Albentosa Hernández, J. I., \& Jiménez Puado, M. J. 2003. “La enseñanza/aprendizaje del inglés como lengua extranjera en edades tempranas." In La enseñanza de la lengua extranjera en la educación infantil. Coords. A. J. Moya Guijarro, \& J. I. Albentosa Hernández. Universidad de Castilla La-Mancha, España: Servicio de Publicaciones de la Universidad de Castilla-La Mancha. 11-42.

Navarro Pablo, M., \& García JimÉnez, E. 2018. “Are CLIL students more motivated? An analysis of affective factors and their relation to language attainment". Porta Linguarum: revista internacional de didáctica de las lenguas extranjeras, 29: 71-90.

RYAN, R. M., \& DECI, E. L. 2002. “An overview of self-determination theory: An organismic dialectical perspective.” In Handbook of self-determination research. Eds. E. L. Deci, \& R.M. Ryan. Rochester, NY: The University of Rochester Press. 3-33.

Seikkula-Leino, J. 2007. "CLIL learning: Achievement levels and affective factors". Language and Education, 21, 4: 328-341.

SYLVÉN, L. K. 2017. Motivation, second language learning and CLIL. A. Applied linguistics perspectives on CLIL. Eds. Llinares, \& T. Morton. Amsterdam: John Benjamins. 51-65.

Sylvén, L. K., \& Thompson, A. S. 2015. "Language learning motivation and CLIL: Is there a connection?" Journal of Immersion and Content-Based Language Education, $3,1: 28-50$. 


\section{APPENDIX}

Table 1. L2 motivation (main models)

\begin{tabular}{|c|c|c|}
\hline SEM (Gadner, 1985) & $\begin{array}{l}\text { SDT (Deci \& Ryan, } \\
\text { 1985) }\end{array}$ & $\begin{array}{l}\text { THE L2 MOTIVATIONAL SELF } \\
\text { SYSTEM (Dörnyei, 2005) }\end{array}$ \\
\hline Integrative motivation & $\begin{array}{l}\text { Intrinsic } \\
\text { motivation }\end{array}$ & .Ideal L2 self \\
\hline \multirow[t]{2}{*}{.Instrumental motivation } & $\begin{array}{l}\text { Extrinsic } \\
\text { motivation }\end{array}$ & .Ought-to L2 self \\
\hline & Amotivation & .L2 learning experience \\
\hline
\end{tabular}

Table 2. L2 motivation in CLIL vs EFL

\begin{tabular}{llll}
\hline PRIMIMARY & CLIL better than EFL & CLIL = EFL & EFL better than CLIL \\
\hline & $\begin{array}{l}\text { Lasagabaster \& López } \\
\text { Beloqui (2015) }\end{array}$ & $\begin{array}{l}\text { Fernández-Fontecha \& } \\
\text { Canga Alonso (2014) }\end{array}$ & \\
SECONDARY & & & \\
& $\begin{array}{l}\text { Doiz, Lasagabaster } \\
\text { and Sierra (2014); }\end{array}$ & $\begin{array}{l}\text { Heras and } \\
\text { Lasagabaster (2011); }\end{array}$ & $(2015)$ \\
& $\begin{array}{l}\text { Lasagabster \& } \\
\text { Sierra (2009) }\end{array}$ & & \\
\hline
\end{tabular}

Table 3. L2 motivation in CLIL vs EFL (gender)

\begin{tabular}{llll}
\hline PRIMARY & $\begin{array}{l}\text { CLIL females better } \\
\text { than CLIL males }\end{array}$ & $\begin{array}{l}\text { CLILfemales }= \\
\text { CLIL males }\end{array}$ & $\begin{array}{l}\text { CLIL males better } \\
\text { than females }\end{array}$ \\
\hline & $\begin{array}{l}\text { Fernández-Fontecha } \\
(2014)\end{array}$ & $\begin{array}{l}\text { Fenández-Fontecha } \\
\text { \& Canga Alonso } \\
(2014)\end{array}$ \\
SECONDARY & & Doiz et al. (2014) & $\begin{array}{l}\text { Heras \& } \\
\text { Lasagabaster (2015) }\end{array}$ \\
& $\begin{array}{l}\text { Lasagabaster \& } \\
\text { Sierra (2009); } \\
\text { Sylvén \& } \\
\text { Thompson (2015) }\end{array}$ & \\
\hline
\end{tabular}

